\title{
Virus Sir-Learning Experience in the Pandemic
}

\section{Umar Farooq Baba}

Dept. of Plastic Surgery and Burns, Sher - i - Kashmir Institute of Medical Sciences, Srinagar, Jammu and Kashmir, India

Corresponding Author: Umar Farooq Baba, Dept. of Plastic Surgery and Burns, Sher - i - Kashmir Institute of Medical Sciences, Srinagar, Jammu and Kashmir, India.

\section{Received Date: 07 October 2021 | Accepted Date: 22 December 2021 | Published Date: 04 January 2022}

Citation: Umar F Baba. (2022). Virus Sir-Learning Experience in the Pandemic. Journal of Clinical Surgery and Research. 3(1); DOI: $10.31579 / 2768-2757 / 034$

Copyright: (92022 Umar Farooq Baba, This is an open-access article distributed under the terms of the Creative Commons Attribution License, which permits unrestricted use, distribution, and reproduction in any medium, provided the original author and source are credited.

\begin{abstract}
:
The COVID-19 pandemic changed us individually as well as our routines, goals, and motives. Rightly so, some changes may last longer. Importantly, the pandemic has made us understand several lessons, and has tried to enhance our positive perspective regarding life and its requirements. We came to know how quickly we are capable of adapting to changes. These adjustments proved beyond doubt that there's not much in life that is truly indispensable. We are practising selfcare in a multitude of ways. We might not have thought of our power of resilience. Again, mental health took over as an epicentre of overall wellbeing, reminding us of the power of 'mind matters' over 'money matters'. The health sector disparities and unpreparedness to combat any sort of pandemic situation surfaced not only in resource-limited countries like ours but the uneasiness of the developed world became exposed. The pandemic had been a harsh learning experience for all of us, irrespective of our position in the spectrum.
\end{abstract}

Keywords: COVID-19; pandemic; lessons; changes

\section{Opinion}

Since December 2019, we've all been whipped by the so called "Chinese Virus.". It is established as a global challenge since the virus has no regard for any frontiers. It is just as much a threat at the state level, where many of the strategic resolutions are framed in the wake of calamity, and at the provincial levels, where people determine whether to comply with guidelines and whether to stand for one another when it comes to the pinch. Everyone among us - from heads of state to administrators to ordinary citizens bear a great deal of responsibility for others' health and well-being.

Before this most of us wouldn't have appreciated terms and phrases like social distancing, flatten the curve, while the idea of putting on masks or being unable to go out in public at all would have seemed erratic. We probably would not have imagined that the busiest thoroughfares in our locales would be deserted; schools and colleges would remain shut for an entire academic session(s), in-person gatherings would be repealed and blockbuster releases would be put on hold indefinitely. We would instinctively want to be close to our family and friends in times of existential danger, to hold their hands and embrace them - but were forbidden to do so, for any act of physical contact might cause illness and death! Such was the scare at the outset of the crisis. The initial weeks of the lockdown brought many of us to the edge of panic and despair. Of course, those were very trying times, and some suffered mightily. The Covid-19 pandemic demonstrates to us the value of freedom - the freedom to move, to be with those we love- for ourselves and for those around us

However, it's not over yet. Some say it is just the end of the beginning, and much more is to follow in the coming times in the form of many socalled 'waves'-some newer, some mutated! There are some burning questions that the Coronavirus sears into our conscience-What next? Once this threat has been overcome and when we awaken in the post-Covid-19 world, will our priorities remain the same? Would we come out changed forever? Will we stick to the resolutions made? and finally, the most important, will we continue to be prepared for any other pandemic in the future? Actually, these are very hard and before time posed questions. But the validity of these queries cannot be questioned.

I wonder that the Virus has been a harsh teacher, making us understand unforgettable lessons and truths, though most bitter, about life. This teacher virus reminds me of the similar whimsical evil character by the same name 'Virus' in a blockbuster of the Indian cinema. Both, though mean and cruel, but definitely taught indispensable lessons to us. At the current date, nobody knows what the ultimate outcome of the crisis will be, but one thing is certain- we are stronger when we act together, and together we will defeat the 'enemy invisible'. The lessons we absorb and the energy we put into making positive choices today will make a meaningful difference tomorrow. While COVID-19 has given rise to new challenges and uncertainties, the pandemic has also yielded some valuable lessons- a silver lining! 
Many say the world has changed forever. The pandemic changed our lifeit has changed us individually, our routines, our life goals, and priorities. Truly so; some changes may last longer than the pandemic itself. But Humanity's memory is short, and what is not ever-present fades quickly. There are lessons worth remembering, including those that might help us survive a future virus or nurture a resilience that could help with life in general.

Foremost, it has taught us how quickly we are capable of adapting to changes. We rolled with these strange new circumstances, adapting to a new routine, a new way of life, without falling apart. Within days to weeks, most adjusted to living their lives differently - work from home, online classes for students, online interaction with friends and relations, spending full time with family, reliving the old, now forgotten hobbies, learning new skills are a few among the many changes. And many of us even started thriving under the newer, relaxed routine. Developing or revisiting hobbies-from cooking and knitting to painting and learning a new language, our renewed enthusiasm for pastimes has helped to recharge our health batteries, not to mention build connections with our families. For example, the simple act of baking bread with a son or daughter can nurture an important life skill, as well as create a cherished memory. In short, we tried to ride out of the pandemic like champions.

We learned that there's not much in life that is truly essential. When all the non-essential business establishments, big and small, were closed, many of us were forced to confront the reality that there are very few things in life that are actually essential. The raging pandemic turned reality upside down. It has taught that anything more than what is needed is a waste. We now realize that the luxuries and several social/ recreational activities that we thought we could never live without are more of a choice than a necessity; some even labeled this wastage of time and money, and completely unnecessary. It is a high time we audit ourselves and redefine the things in life we call necessities, wants, and needs. Practically, it means changing our daily habits, redirecting our monthly budgets, deciding to donate more money to charity, or shifting our financial priorities in some other direction.

Inherently, we have resilience as a means to deal with the crisis. As a part of our psyche, we have the capacity for resilience. The concept of resilience is an effective reservoir inherent in all of us - being the product of evolution, our ancestors going through catastrophes, including wars, famines, and plagues. We are stronger than we know; the onslaught taught us about our resilience, strength, and courage. People have practiced selfcare in a multitude of ways during the pandemic as they were forced to adjust to new work schedules, changed daily routines, and cut back on socializing.

Forced into our own homes with just our immediate families, we quickly learned what is truly important in life, rest everything else is really secondary. When daily rituals and routines we've always taken for granted got disrupted, it lent us a new sense of appreciation for the small things in life. We could realize that there lies wonder in everything around us. We got to know the importance of visiting outdoors and cherishing outdoor activities, including sporting events. Before the coronavirus, many of us had taken human interaction for granted. Spending time with our immediate loved ones now, however, has taken centre stage. Despite the frustrations of daily confinement, the true importance of our family and friends got unfurled. As restrictions begin to lift, seeing those we haven't been able to connect with face-to-face will feel that much more special. People during the pandemic realized the importance of human connection and realized they need it. Many of us have become aware of how much we need other people - many have managed to maintain their social connections, even if they had to use technology to keep in touch, even people who aren't necessarily friends or family are important. Loneliness has been found to suppress the immune system and be a precursor to some diseases. Even for introverted folks, the smallest circle is preferable to no circle at all.

Prevention is better than cure. This age-old adage is getting more power and strength in the current circumstances. People have understood the fact that when it comes to our health and wellness, there is power in ownership and prevention. Pandemic has made people more hygienic and healthconscious. Eating a healthy balanced diet with particular stress on 'immune boosting' one, daily exercise schedule, yoga, and meditation, cut back on alcohol are a few new additions to our daily engagement. Frequent handwashing/ hygiene awareness, respiratory etiquettes, and social distancing have garnered greater focus. It necessitated a global effort to ensure that everyone practiced behaviours to keep others healthy as well.

This included the practiced preventive measures such as the widespread wearing of masks, maintaining a safe distance, and washing hands frequently. In addition, people have learned a lot about respiratory pathogens, especially viruses, their mode of spread, and various preventive measures. The pandemic has drastically accelerated the permeation of this knowledge into the communities and has clarified the significance of asymptomatic or pre-symptomatic transmission of the disease. It became clear that breathing and talking, not just coughing, generate aerosols and that these can transmit the virus.

Our psyche of 'money matters' changed to 'mind matters'. There was a rise in reported mental health problems that have been described as "a second pandemic," highlighting mental health as an issue that needs to be addressed. The number of mental health disorders that were on the rise before the pandemic are surging as people grapple with such matters as juggling work and childcare, job loss, isolation, and losing a loved one. Reports show that having COVID-19 may contribute to its lingering symptoms, which can include "foggy mind," anxiety, depression, and post-traumatic stress disorder. The pandemic has prompted us to cope with stress, and many started seeking out new strategies to counter the stress in form of yoga, meditation, keeping up with friends and family, or mindfulness in reducing stress and improving mental wellbeing.

Community is essential — and technology too. Nothing compares to an inperson interaction. Telehealth/e-health/telemedicine has become the new normal. Doctors and patients who have used telehealth (technology that allows them to conduct medical care remotely) and found that it can work well for certain appointments. While telehealth won't work for everyone and there are still problems for which we need to see a doctor in person, the pandemic switched over to new platforms for remote patient visits. We have learned how to work through the social isolation that our patients and families are experiencing, finding novel ways to communicate via the use of online platforms. The use of telemedicine has greatly improved our ability to continue a provider relationship with our patients.

The pandemic highlights the importance of social interaction and social interdependence. We being social animals, there is a universal need for social interaction, even if it is as small as a few words exchange with a delivery man, neighbour, or some other acquittance. One of the positive impacts is spending more time together with family. Whether that means resolving to turn our phones on silent or to put them away completely, this mindfulness can help strengthen our relationships forever. Secondly, in most of our endeavours, we are interdependent- success cannot be achieved without the cooperation of others at all levels. Ignoring this vital issue can lead us to no man's land. Here it should be crystal clear that all of the humanity sails in the same boat. The virus can be defeated somewhere only when it is defeated everywhere. It underlines a very important lesson that we cannot achieve security (be it social/ health/ fiscal) in isolation, within the borders of our nation, culture, class, or religion. 
It is the public health catastrophe of our generation. The pandemic unveiled many underlying issues that we've long known existed, specifically health disparities and the ongoing disinvestment in our public health systems. There must be urgent actions taken to address these challenges, as well as ongoing commitment to address them long-term so that the lessons learned are not forgotten. it has taught us that in response to a pandemic, we need a scientific and public health-based response that needs to be communicated very clearly. Perhaps the biggest one is that public health is all about preparedness. By the time we reacted, it was often already too late. We need to be better prepared for the future.

Sometimes you need a dose of humility. Scientists and non-scientists alike learned that even a microscopic entity like a virus can be more powerful than we are. We've seen that we have to take these pathogens seriously. So, we have to have respect for the unknown and respect science, but also try to give scientists the benefit of the doubt. We are confronted with the true uncertainty of human existence and the true vulnerability of human life. How often have so many of us believed that we are supreme masters of the world around us?

The pandemic has revealed a vast sea of kindness and benevolence in our communities around the world. It has led to countless acts of selfless heroism in hospitals and freshly created care homes/ centres. It has impelled many of us to use our greatest strengths to serve our greatest purposes, suddenly giving our lives new, inspiring meaning. This is the lesson that we must take into the post-Covid-19 world: The time has come to mobilize this goodness in our midst, rather than drive it to the side lines through institutions and incentive systems that reward selfishness and predatory competitiveness. The pandemic shows us that the goals of all these domains must always be the same: contributing to the fulfilment of human needs and purposes. We have been much more grateful and appreciative about things and have become more charitable. This requires us to cooperate locally when we face local challenges, nationally when we face national challenges, and globally when we face global challenges.

The religious insight is that all people are created in the image of God. It calls us to recognize that everyone on earth is worthy of our respect and care. It forces us to appreciate the true value of many people whose roles in society tend to be undervalued: the nurses, the hospital orderlies, the people sitting at the checkout counters in supermarkets, the delivery personnel, the many nameless strangers who suddenly offer help to the old and vulnerable. Rekindle the fire. The smiles of gratitude hidden under the masks of patients in dire need of care are priceless. It's long overdue-delivery drivers, supermarket employees, health care professionals, and other essential workers are finally receiving the recognition they deserve. The sacrifices they've particularly made during this pandemic haven't gone unnoticed. Showing gratitude for these everyday heroes will go a long way toward building lasting goodwill.

A big change which was appreciated and acknowledged by one and all including environmentalists is the change in the quality of the air we breathe, water quality with its contained animal population in our body bodies, and so on. It is one of the major positive effects of the crisis by lesson. It is crystal clear that environmental pollution is the handwork of humans and that it is, undoubtedly, possible to keep it at minimal permissible levels to save Mother Earth for posterity.

Once again vaccines are proving to be a powerful tool for preventing disease. But caution that a vaccine is not a magic bullet-and that scientists can't always produce one that works well. Pandemic did not treat everyone equally. Some suffered a lot, while others were less. However, it is agreed upon that all of us share the brunt of sufferings in one way or other and no soul remained untouched. So, the pandemic has proved to be a learning experience for us, making us vigilant of future global upsurges demanding prompt actions and preparedness to face any eventuality.



This work is licensed under Creative Commons Attribution 4.0 License

To Submit Your Article Click Here:

Submit Manuscript
Ready to submit your research? Choose Auctores and benefit from:

$>$ fast, convenient online submission

$>$ rigorous peer review by experienced research in your field

$>$ rapid publication on acceptance

$>$ authors retain copyrights

$>$ unique DOI for all articles

$>$ immediate, unrestricted online access

At Auctores, research is always in progress.

Learn more https://auctoresonline.org/journals/journal-of-clinical-surgery-andresearch 